\title{
Acetate-induced apoptosis in colorectal carcinoma cells involves lysosomal membrane permeabilization and cathepsin $\mathrm{D}$ release
}

\author{
C Marques $^{1,2}$, CS F Oliveira ${ }^{1,2}$, S Alves ${ }^{1}$, SR Chaves ${ }^{1}$, OP Coutinho ${ }^{1}$, M Côrte-Real ${ }^{1}$ and A Preto ${ }^{\star, 1}$
}

Colorectal carcinoma (CRC) is one of the most common causes of cancer-related mortality. Short-chain fatty acids secreted by dietary propionibacteria from the intestine, such as acetate, induce apoptosis in CRC cells and may therefore be relevant in CRC prevention and therapy. We previously reported that acetic acid-induced apoptosis in Saccharomyces cerevisiae cells involves partial vacuole permeabilization and release of Pep4p, the yeast cathepsin $D(C a t D)$, which has a protective role in this process. In cancer cells, lysosomes have emerged as key players in apoptosis through selective lysosomal membrane permeabilization (LMP) and release of cathepsins. However, the role of CatD in CRC survival is controversial and has not been assessed in response to acetate. We aimed to ascertain whether LMP and CatD are involved in acetate-induced apoptosis in CRC cells. We showed that acetate per se inhibits proliferation and induces apoptosis. More importantly, we uncovered that acetate triggers LMP and CatD release to the cytosol. Pepstatin A (a CatD inhibitor) but not E64d (a cathepsin B and L inhibitor) increased acetateinduced apoptosis of CRC cells, suggesting that CatD has a protective role in this process. Our data indicate that acetate induces LMP and subsequent release of CatD in CRC cells undergoing apoptosis, and suggest exploiting novel strategies using acetate as a prevention/therapeutic agent in CRC, through simultaneous treatment with CatD inhibitors.

Cell Death and Disease (2013) 4, e507; doi:10.1038/cddis.2013.29; published online 21 February 2013

Subject Category: Cancer

Colorectal carcinoma $(\mathrm{CRC})$ is a leading cause of cancer death worldwide (GLOBOCAN 2008), and thus finding new prevention and therapeutic approaches is of prime importance. Propionibacteria, found in fiber-rich food and dairy products, produce short-chain fatty acids (SCFA), mainly propionate and acetate, which induce apoptosis in CRC cells. Their potential in cancer prevention and therapy has thus been proposed by several authors ${ }^{1-6}$ and understanding the mechanisms underlying acetate-induced cell death should provide new prevention/therapeutic strategies in CRC.

The lysosomal pathway of apoptosis involves partial lysosomal membrane permeabilization (LMP), with subsequent release of proteases (such as cathepsins) into the cytosol. ${ }^{7,8}$ However, the role of this pathway in cancer is controversial. Transformation can lead to several lysosomal changes, such as increased lysosomal volume, secretion of proteases and total protease activity, ${ }^{9}$ and changes in the subcellular localization of cathepsins B, D and L (CatB, CatD and CatL, respectively). ${ }^{10}$ Such alterations become prooncogenic when enhanced secretion of cathepsins initiates proteolytic pathways that increase neoplastic progression. ${ }^{11}$ Increased cysteine cathepsin activity is important for tumor angiogenesis, proliferation, growth and invasion. ${ }^{12}$
Cathepsins are often overexpressed in human cancers, and high expression levels have been associated with increased risk of relapse and poor prognosis. ${ }^{13}$ In contrast to their tumorpromoting effects, there is also evidence that they function as tumor suppressors. ${ }^{14}$ This opposing role depends on the context: if cathepsins are released intracellularly they contribute to cancer cell death, but if released extracellularly they break down the extracellular matrix, stimulating angiogenesis and migration. ${ }^{10}$

CatD is a lysosomal aspartyl protease involved in autophagy and apoptosis, thus having a crucial role in cell fate and tissue homeostasis. ${ }^{15}$ CatD has emerged as a central player in the apoptotic response, although its role is cell-type and context-dependent. Expression patterns of CatD protein are divergent in $\mathrm{CRC}$, suggesting a complex regulation and function of this protease, ${ }^{16,17}$ though its precise role remains poorly understood.

We previously showed that the vacuolar protease Pep4p, the Saccharomyces cerevisiae CatD, translocates to the cytosol during acetic acid-induced apoptosis, suggesting that the release of a vacuolar protease during regulated cell death is also conserved in yeast. ${ }^{18}$ We additionally showed that Pep4p has a role in cell protection rather than in the execution

\footnotetext{
${ }^{1}$ CBMA (Centre of Molecular and Environmental Biology), Department of Biology, University of Minho, Campus de Gualtar, Braga 4710-057, Portugal ${ }^{*}$ Corresponding author: A Preto, CBMA (Centre of Molecular and Environmental Biology), Department of Biology, University of Minho, Campus de Gualtar, Braga 4710-057, Portugal. Tel: + 35125360 1511; Fax: + 35125367 8980; E-mail: apreto @ bio.uminho.pt

${ }^{2}$ These authors contributed equally to this work.

Keywords: Cathepsin-D; lysosomal membrane permeabilization (LMP); apoptosis; acetate; colorectal carcinoma

Abbreviations: AO, Acridine Orange; AV, annexin V; BrdU, bromodeoxyuridine; CatB, cathepsin B; CatD, cathepsin D; CatL, cathepsin L; CRC, colorectal carcinoma; E64d, (2S,3S)-trans-Epoxysuccinyl-L-leucylamido-3-methylbutane ethyl ester; LMP, lysosomal membrane permeabilization; MTT, 3-[4,5-dimethylthiazol-2-yl]-2,5diphenyltetrazolium bromide; PI, propidium iodide; PstA, pepstatin A; SCFA, short-chain fatty acids; SRB, sulforhodamine B; TUNEL, terminal deoxynucleotidyl transferase-mediated dUTP-fluorescein nick end labeling

Received 12.11.12; revised 23.12.12; accepted 02.1.13; Edited by A Stephanou
} 
of acetic acid-induced cell death. These results raised the possibility that partial LMP and consequent CatD release was involved in the response of $\mathrm{CRC}$ cells to acetate. Here, we show that CatD is released from lysosomes and might protect CRC cells from acetate-induced apoptosis. Our data therefore establish the lysosome and CatD as novel targets of acetate in $\mathrm{CRC}$ cells and indicate that CatD activity has important repercussions in the sensitivity of $\mathrm{CRC}$ to acetate produced in the intestine that might have prevention/therapeutic implications.

\section{Results}

Acetate induces apoptosis and inhibits cell proliferation in CRC cell lines. CRC-derived cell lines HCT-15 and RKO were treated with different concentrations of acetate for 24 and $48 \mathrm{~h}$ and cell viability assessed with the 3-[4,5dimethylthiazol-2-yl]-2,5-diphenyltetrazolium bromide (MTT) reduction test. After $24 \mathrm{~h}$, there was no statistically significant decrease in viability of acetate-treated cells in either cell line, in comparison with untreated cells (not shown). The halfmaximal inhibitory concentration $\left(\mathrm{IC}_{50}\right)$ of acetate was therefore calculated from the mean values of MTT reduction after $48 \mathrm{~h}$ of treatment: $70 \mathrm{mM}$ and $110 \mathrm{mM}$ for HCT-15 and RKO cells, respectively (Figure $1 \mathrm{a}$ ). $\mathrm{IC}_{50}, 2 \times \mathrm{IC}_{50}$ and an intermediate concentration of acetate were used in subsequent studies.

The decrease in cell viability determined by MTT assay might be due to decreased cell proliferation, increased cell death or both. We therefore assessed cell proliferation after exposure to acetate using sulforhodamine B (SRB) and bromodeoxyuridine (BrdU) assays and apoptosis using Annexin V/propidium iodide (AV/PI), caspase activity and terminal deoxynucleotidyl transferase-mediated dUTP-fluorescein nick end labeling (TUNEL) assays, as well as sub-G1 population analysis by flow cytometry. The $\mathrm{IC}_{50}$ of acetate reduced cell proliferation by approximately $30 \%$ and $65 \%$ in HCT-15 and RKO cells, respectively, as determined by SRB assay (Figure $1 \mathrm{~b}$ ). In HCT-15 cells, $\mathrm{IC}_{50}$ and $2 \times \mathrm{IC}_{50}$ of acetate reduced proliferation by approximately $17 \%$ and $75 \%$, respectively, as determined by BrdU assay (Figures 1c and d).

We next analyzed cell death through AV/PI staining and found that acetate induced exposure of phosphatidylserine to the outer leaflet of the plasma membrane in HCT-15 cells in a dose-dependent manner (Figure 2a). The number of cells stained with $\mathrm{AV}(\mathrm{AV}+\mathrm{PI}-$ plus $\mathrm{AV}+\mathrm{PI}+)$ increased from $3.9 \%$ in the untreated control to $8.0,18.2$ and $47.9 \%$ after exposure to 70,100 and $140 \mathrm{mM}$ acetate, respectively, and to $49.1 \%$ when cells were exposed to etoposide for $48 \mathrm{~h}$ (Figure 2b). Levels of necrotic cells $(\mathrm{AV}-\mathrm{PI}+$ ) after exposure to 70 or $100 \mathrm{mM}$ acetate were very low. A higher dose of acetate $(140 \mathrm{mM})$ increased the number of necrotic cells $(\sim 4 \% \mathrm{AV}-/ \mathrm{PI}+)$, similarly to etoposide, although the majority of the population ( $48 \%$ ) was in early and late apoptosis $(\mathrm{AV}+\mathrm{PI}-$ plus $\mathrm{AV}+\mathrm{PI}+$ ) (Figure 2b). These results led us to conclude that acetate induces apoptosis rather than necrosis. Accordingly, caspase 3 was also activated in HCT-15 cells, as cleavage of the fluorogenic caspase 3 substrate z-DEVD-AMC, expressed in arbitrary fluorescence units $/ \mathrm{min} / \mu \mathrm{g}$ protein, increased from 3.6 in HCT-15 control cells (untreated) to 24.4 after exposure to
$140 \mathrm{mM}$ acetate (Figure 2c). Similar results were obtained when activation of total caspases was assessed by labeling with the fluorescent pan-caspase inhibitor FICT-VAD-fmk (not shown). We also assessed the levels of DNA strand breaks in both the cell lines by TUNEL assay. In comparison to the negative control, there were no significant differences in the number of HCT-15 apoptotic cells after $48 \mathrm{~h}$ of treatment with $70 \mathrm{mM}$ acetate $\left(\mathrm{IC}_{50}\right)(0.5 \%$ versus $1.6 \%$; Figure $3 \mathrm{a})$, though phenotypic alterations typical of apoptosis (such as apoptotic bodies) were observed (Figure 3b). However, the number of apoptotic cells increased significantly $(7.2 \%)$ after $48 \mathrm{~h}$ of treatment with $140 \mathrm{mM}$ acetate $\left(2 \times \mathrm{IC}_{50}\right)$ (Figure 3a). Exposure to $110 \mathrm{mM}$ acetate $\left(\mathrm{IC}_{50}\right)$ induced a minor increase in the number of apoptotic RKO cells, compared with low basal apoptotic levels (1.6\% versus $0.3 \%$; Figure $3 a$ ), but again with evident phenotypic alterations (Figure $3 b$ ). When treated with $220 \mathrm{mM}$ acetate $\left(2 \times \mathrm{IC}_{50}\right)$, the number of apoptotic RKO cells increased significantly (65.5\%; Figure 3a). Acetate also led to a dose-dependent increase in the sub-G1 peak of HCT-15 cells, indicative of an apoptotic sub-population, and similar to that of cells treated with etoposide (Figure $5 \mathrm{~b}$ ). Two peaks corresponding to the $\mathrm{G} 1$ and $\mathrm{G} 2 / \mathrm{M}$ phases of the cell cycle were evident in DNA content histograms of HCT-15 control (untreated) cells, with very few cells in the hypodiploid sub-G1 cell-cycle phase ( $2 \%$ of the total events acquired). Exposure to etoposide or $140 \mathrm{mM}$ acetate greatly increased the percentage of hypodiploid cells to approximately $70 \%$ and $35 \%$, respectively (Figure $5 \mathrm{~b}$ ).

It has been reported that the $\mathrm{pH}$ influences the cell death pathway induced by SCFA produced by propionibacteria, that is, SCFA trigger apoptosis at $\mathrm{pH} 7.5$ in HT-29 cells but necrosis at $\mathrm{pH} 5.5{ }^{1}$ In our study, the $\mathrm{pH}$ of the culture medium after $48 \mathrm{~h}$ of incubation with acetate was closer to 7.5 than to 5.5 in both HCT-15 and RKO cell lines and was similar to that of the control culture (Table 1). In RKO cells, the $\mathrm{pH}$ of the control culture medium $(\mathrm{pH}=8.00)$ was higher than that of HCT-15 cells $(\mathrm{pH}=7.45)$, probably due to the different composition of the growth medium (DMEM (Dulbecco's Modified Eagle's Medium) for RKO cells and RPMI for HCT-15 cells) and to the different growth rates of these cell lines. Taken together, our results show that, under our experimental conditions, acetate induced apoptosis.

Acetate induces lysosomal permeabilization and cathepsin D release to the cytosol. We next investigated whether the lysosomal pathway was involved in acetateinduced apoptosis in CRC cells. We measured LMP both by staining with the lysosomotropic agent Acridine Orange (AO) and by immunoblot detection of CatD in cytosolic fractions. $\mathrm{AO}$ is a weak base that moves freely across membranes when uncharged and accumulates in acidic compartments like lysosomes in its protonated form, where it forms aggregates that fluoresce bright red. LMP is associated with proton release, which renders lysosomes more alkaline and hence with decreased red fluorescence. LMP was monitored qualitatively by fluorescence microscopy and quantitatively by flow cytometry, by measuring the percentage of cells with loss of lysosomal AO red fluorescence. Etoposide was used as a positive control, as it destabilizes lysosomes and induces LMP through CatD release to the cytosol. ${ }^{19-21}$ 

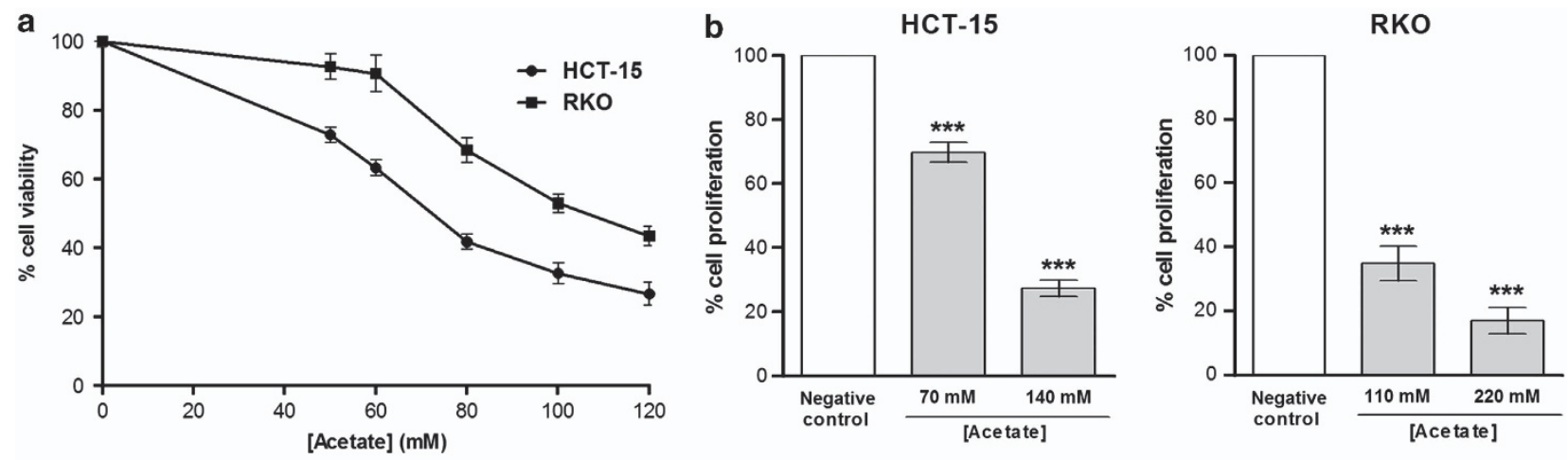

d HCT-15

[Acetate]

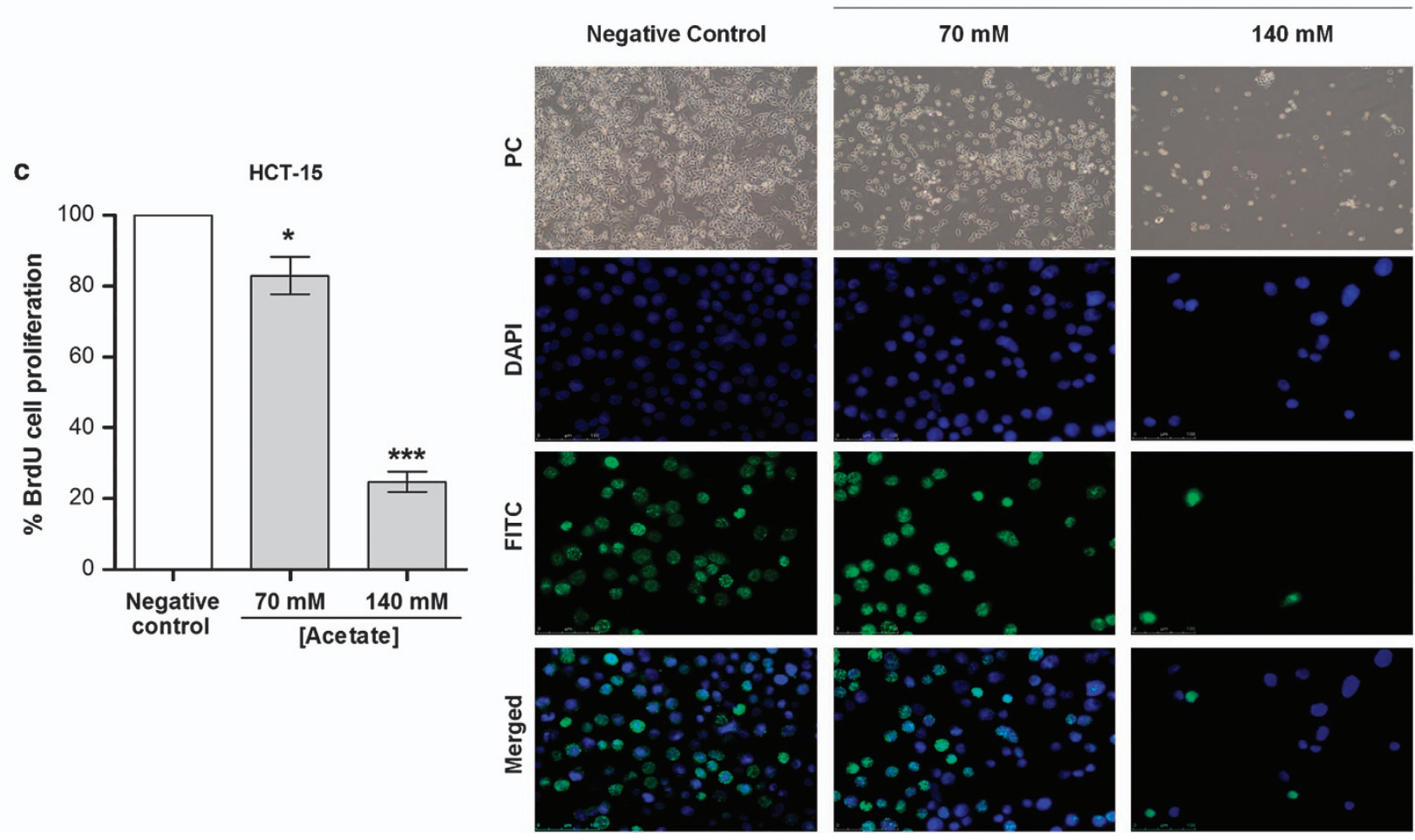

Figure 1 Determination of acetate $\mathrm{IC}_{50}$ values and proliferation analysis in $\mathrm{CRC}$ cell lines treated with acetate. (a) HCT-15 and RKO cells were incubated with different concentrations of acetate for $48 \mathrm{~h}$ or with fresh complete medium as a negative control, and IC $\mathrm{C}_{50}$ values determined by MTT reduction assay. (b) Cell proliferation analysis by SRB assay in CRC cells treated with acetate. Cells were incubated with I $\mathrm{C}_{50}$ and $2 \times \mathrm{IC}_{50}$ concentrations of acetate (respectively, $70 \mathrm{mM}$ and $140 \mathrm{mM}$ for HCT-15 and $110 \mathrm{mM}$ and $220 \mathrm{mM}$ for RKO) for $48 \mathrm{~h}$. Values represent mean \pm S.E.M. of at least three independent experiments. ${ }^{* \star} P \leq 0.001$, compared with negative control cells. (c) Cell proliferation analysis by BrdU incorporation assay in HCT-15 cells treated with acetate $(70 \mathrm{mM}$ and $140 \mathrm{mM})$ for $48 \mathrm{~h}$; values represent mean \pm S.E.M. of at least three independent experiments ${ }^{*} P \leq 0.05$; ${ }^{* *} P \leq 0.001$, compared with negative control cells. (d) Representative photographs of BrdU incorporation assay in HCT-15 cells treated with acetate $(70 \mathrm{mM}$ and $140 \mathrm{mM})$ for $48 \mathrm{~h}$. phase contrast (PC; $\times 100)$; DAPI (4',6-diamidino-2-phenylindole), FITC (fluorescein isothiocyanate) and merged $(\times 200)$ were obtained by fluorescence microscopy

Fluorescence microscopy analysis of both the cell lines stained with $\mathrm{AO}$ showed that a high percentage of control cells exhibited intact acidic lysosomes (i. e., high levels of red fluorescence corresponding to accumulation of $\mathrm{AO}$ in acidic lysosomes) and a reduced percentage of cells with diffused green fluorescence (corresponding to non-lysosomal $\mathrm{AO}$ ) (Figure 4a). By contrast, exposure to acetate led to a decrease in the percentage of cells with red fluorescence, associated with an increase in the percentage of cells with green fluorescence, indicative of LMP (Figure 4a). Similar results were obtained in cells treated with etoposide. These differences were more pronounced in cells treated with $2 \times I_{50}$ acetate than in cells treated with $I_{50}$ concentrations. Quantification of AO-stained cells was performed by flow cytometry; cells with red fluorescence levels lower than the threshold of AO-positive staining of untreated cells were considered to exhibit LMP. Cells with LMP increased from approximately $3.6 \%$ in untreated cells to $11.7,25.8$ and $49.1 \%$ in cells exposed to $70 \mathrm{mM}\left(\mathrm{IC}_{50}\right), 100 \mathrm{mM}$ and $140 \mathrm{mM}$ $\left(2 \times \mathrm{IC}_{50}\right)$ acetate, respectively (Figure $\left.4 \mathrm{c}\right)$. These results demonstrate that acetate induces LMP in a dose-dependent manner. 
a
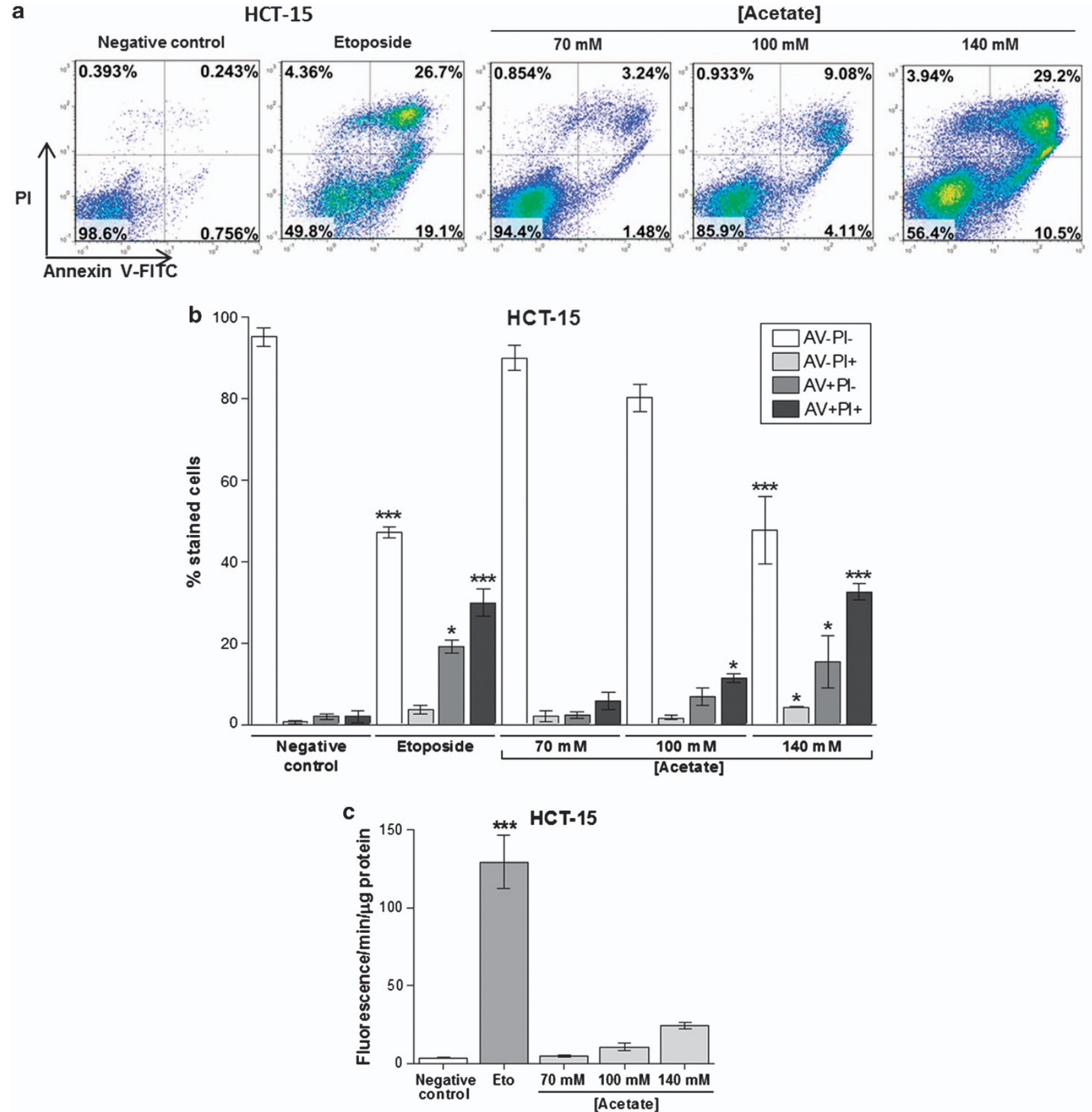

Figure 2 Acetate induces apoptosis and not necrosis in CRC cells. Apoptosis determined by Annexin V fluorescein isothiocyanate (AV-FITC) and propidium iodide (PI) assay in HCT-15 cells after incubation with $70 \mathrm{mM}, 100 \mathrm{mM}$ and $140 \mathrm{mM}$ of acetate for $48 \mathrm{~h}$. Cells were incubated with fresh complete medium or etoposide (50 $\mu \mathrm{M})$ as a negative and positive control, respectively. (a) Representative histograms of HCT-15 cells double-labeled with AV and PI. Percentages of apoptotic cells (positive for AV) are the sum of the lower and upper right panels. (b) Quantitative analysis of AV/PI staining in HCT-15 cells. Values represent mean \pm S.E.M. of at least three independent experiments. ${ }^{*} P \leq 0.05$; ${ }^{* * *} P \leq 0.001$, comparing each subset of cells $(\mathrm{AV}-\mathrm{Pl}-, \mathrm{AV}-\mathrm{PI}+, \mathrm{AV}+\mathrm{PI}-, \mathrm{AV}+\mathrm{PI}+)$ to the respective negative control cells. (c) Quantitative analysis of caspase 3 activity in HCT-15 cells after incubation with $70 \mathrm{mM}, 100 \mathrm{mM}$ and $140 \mathrm{mM}$ of acetate for $48 \mathrm{~h}$. Values represent mean \pm S.E.M. of three independent experiments. ${ }^{*} P \leq 0.05 ;{ }^{* *} P \leq 0.01 ;{ }^{* * *} P \leq 0.001$, compared with negative control cells

As lysosomal proteases such as CatD are released from lysosomes to the cytosol after LMP, their detection in the cytosolic fraction is indicative of LMP. We therefore treated HCT-15 and RKO CRC cells with two concentrations of acetate ( $\mathrm{IC}_{50}$ and $2 \times \mathrm{IC}_{50}$ for each cell line), or with etoposide, and detected CatD in whole-cell extracts and in cytosolic fractions by western blot (Figure 4d). We found that CatD is expressed in whole-cell lysates and that untreated cells exhibited very low levels of CatD in the cytosol. Notably, we found that exposure to etoposide and to $\mathrm{IC}_{50}$ and $2 \times \mathrm{IC}_{50}$ concentrations of acetate led to CatD release to the cytosol, indicating that acetate induces LMP in a concentration-dependent manner and further suggesting that acetate induces a lysosomal pathway of apoptosis in both the cell lines. We also observed that exposure to acetate 
a

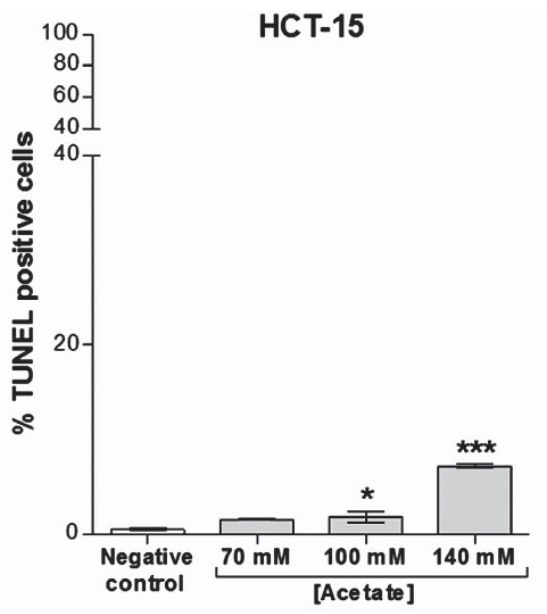

b
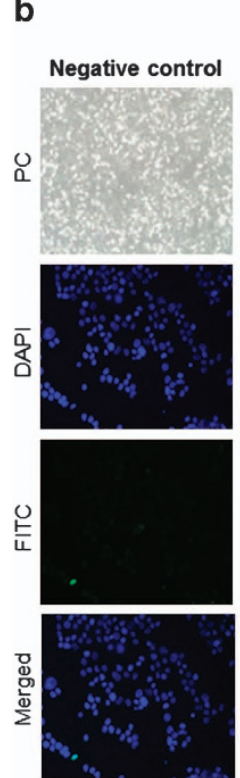

HCT-15
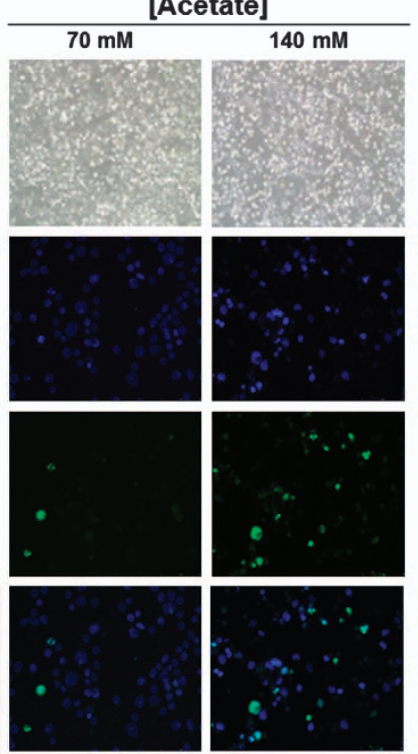
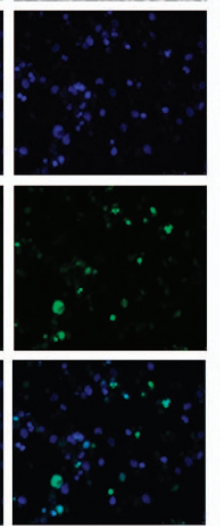

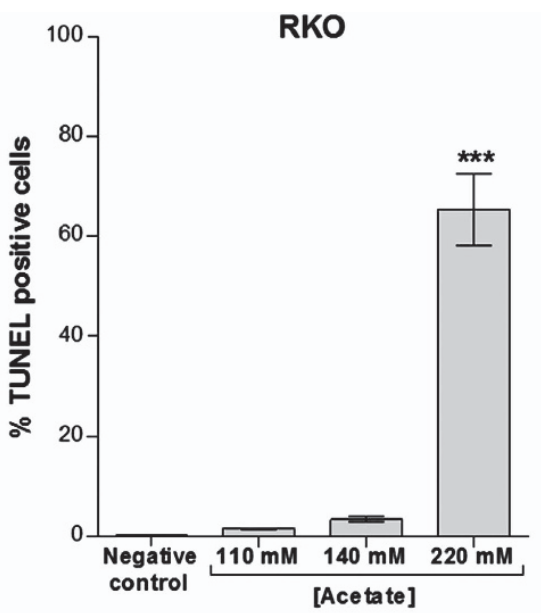

RKO
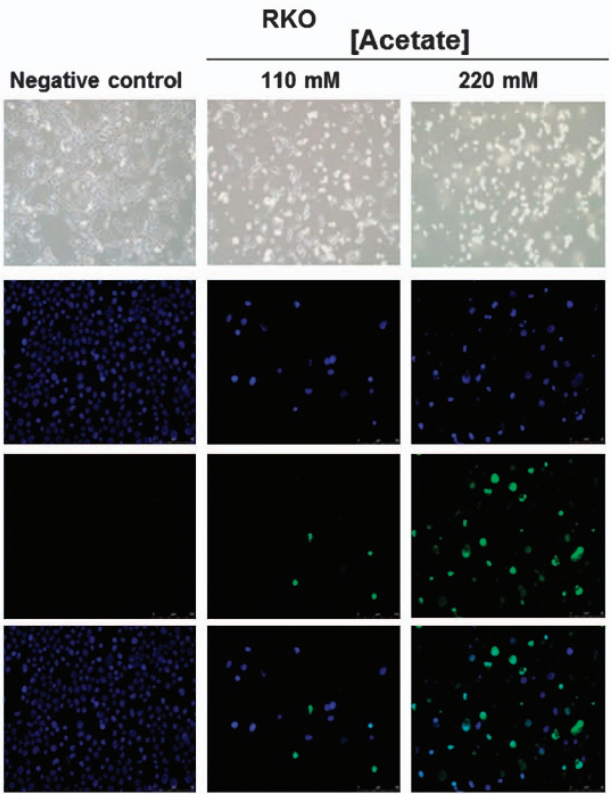

Figure 3 Acetate increases levels of TUNEL-positive cells. Apoptosis analysis in HCT-15 and RKO cells by TUNEL assay, after incubation with IC ${ }_{50}$ and $2 \times I_{50}$ acetate concentrations ( $70 \mathrm{mM}$ and $140 \mathrm{mM}$ for HCT-15; $110 \mathrm{mM}$ and $220 \mathrm{mM}$ for RKO) for $48 \mathrm{~h}$. (a) Analysis of TUNEL assay in HCT15 and RKO cells. Values represent mean \pm S.E.M. of at least three independent experiments. ${ }^{*} P \leq 0.05$; ${ }^{\star \star \star} P \leq 0.001$ compared with negative control cells. (b) Representative images $(\times 200)$ of DAPI (4',6diamidino-2-phenylindole), FITC (fluorescein isothiocyanate) and merged were obtained by fluorescence microscopy. PC, phase contrast

increased Pro-CatD levels in the cytosol of both the cell lines (Figure 4d). The apparent decrease in cytosolic Pro-CatD levels in $\mathrm{RKO}$ cells treated with $2 \times \mathrm{IC}_{50}$ compared with $\mathrm{IC}_{50}$ concentrations of acetate seems to be due to increased processing to mature CatD.

\section{Cathepsin D release protects cells from acetate-induced} apoptosis. To test whether the apoptotic phenotype of HCT-15 and RKO cells exposed to acetate depends on CatD, we inhibited lysosomal CatD with pepstatin A (PstA) and cathepsins $B$ (CatB) and $L$ (CatL) with (2S,3S)-transEpoxysuccinyl-L-leucylamido-3-methylbutane ethyl ester (E64d). PstA, but not E64d, increased apoptotic levels induced by acetate (Figure $5 \mathrm{a}$ ). Indeed, incubation of HCT-15 cells and RKO with PstA before incubation with the
$2 \times \mathrm{IC}_{50}$ concentration of acetate increased the number of TUNEL-positive cells, though only reaching statistical significance in HCT-15. E64d did not significantly alter apoptotic levels of either cell line under the same conditions (Figure 5a). PstA-treated HCT-15 cells exposed to acetate also exhibited a higher percentage of cells with sub-G1 DNA content than cells treated with acetate alone, indicative of higher apoptotic levels (Figures $5 b$ and c). By contrast, inhibition of CatD in cells exposed to etoposide decreased the sub-G1 population (Figures $5 \mathrm{~b}$ and $\mathrm{c}$ ), in agreement with previous reports showing that CatD has a pro-apoptotic role in etoposide-induced cell death. ${ }^{21}$ These results therefore indicate that CatD has a protective role in acetate-induced apoptosis in CRC cells, as has been observed in S. cerevisiae cells for Pep4p, the human CatD ortholog. ${ }^{18}$ 
a

HCT-15

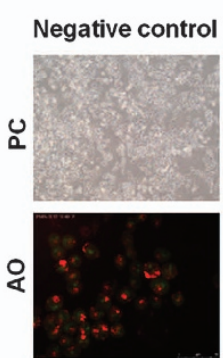

RKO
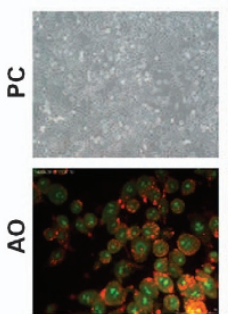

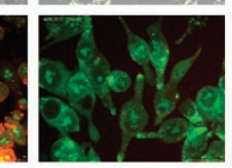

Etoposide
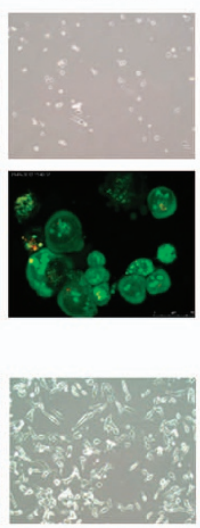

HCT-15
[Acetate]

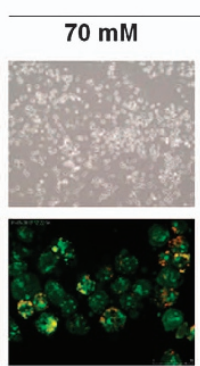

$110 \mathrm{mM}$

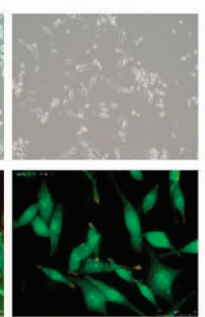

$100 \mathrm{mM}$
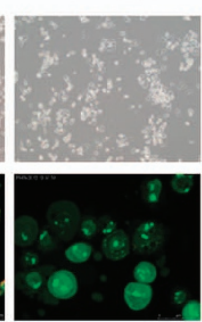

$140 \mathrm{mM}$
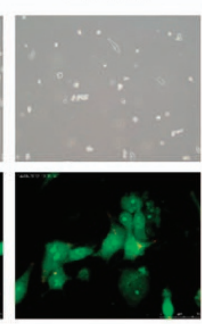

$140 \mathrm{mM}$

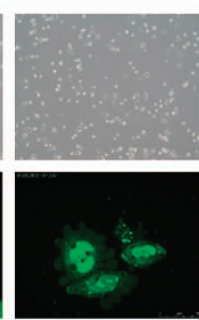

$220 \mathrm{mM}$

b
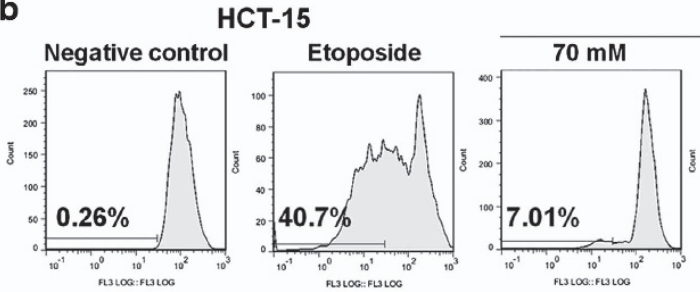

[Acetate]

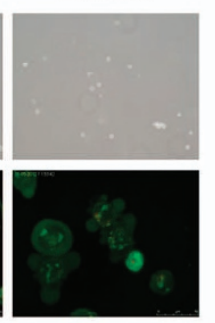

C
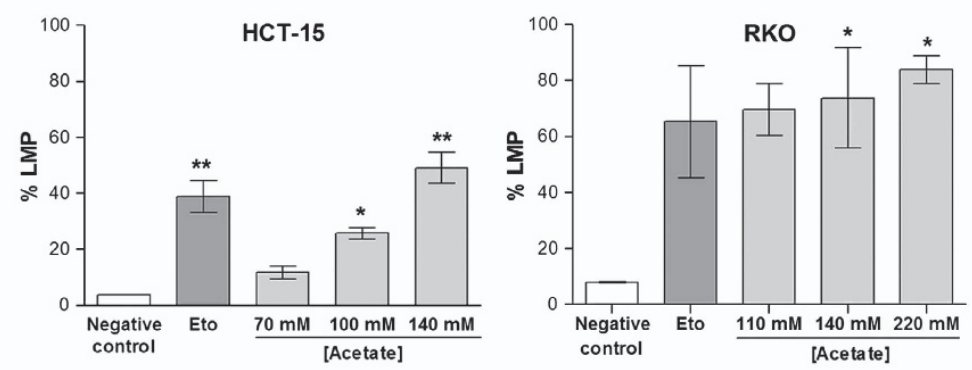

d
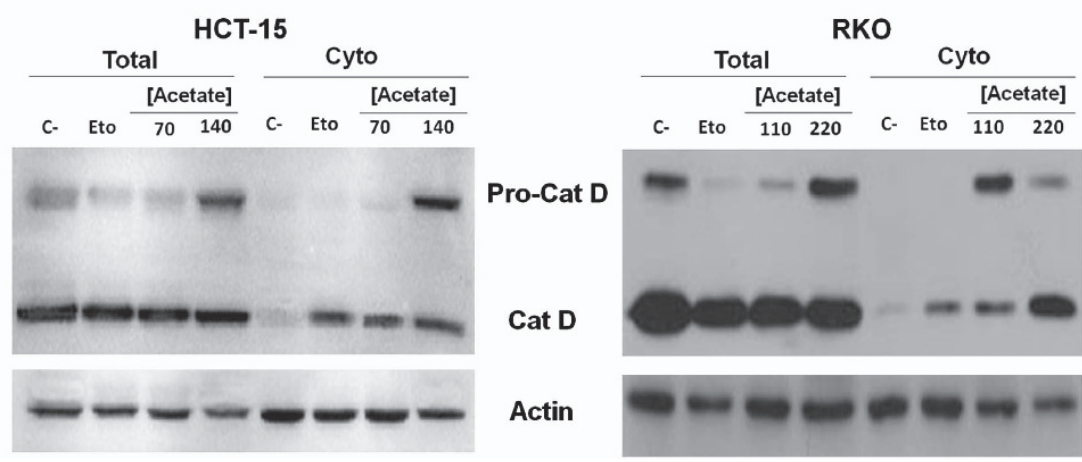

Figure 4 Acetate induces LMP, analyzed by lysosomal pH alterations and CatD release to the cytosol. (a) HCT-15 and RKO cells were incubated with acetate ( $70 \mathrm{mM}, 100 \mathrm{mM}$ and $140 \mathrm{mM}$, for HCT-15 cells; $110 \mathrm{mM}, 140 \mathrm{mM}$ and $220 \mathrm{mM}$, for RKO cells) for $48 \mathrm{~h}$ or with fresh complete medium or etoposide (50 $\mu \mathrm{M}$ ) as a negative and positive control, respectively. LMP was detected by AO staining and visualization by fluorescence microscopy. Representative images $(\times 400)$ are shown. (b) Representative images of monoparametric histograms of green fluorescence (FL3 area (log)) in HCT-15 cells treated as in (a). (c) Percentage of HCT-15 and RKO cells displaying LMP quantified by flow cytometry analysis of $A O$ staining after exposure to acetate as described in (a). Values represent mean \pm S.E.M. of three independent experiments. ${ }^{*} P \leq 0.05$; ${ }^{* \star} P \leq 0.01$ compared with negative control cells. (d) Effect of acetate on the expression and release of cathepsin D to the cytosol in HCT-15 and RKO cells, comparing whole-cell lysates (total) and cytosolic fractions (cyto). Cells were treated with $\mathrm{IC}_{50}$ and $2 \times \mathrm{IC}_{50}$ acetate concentrations (respectively, $70 \mathrm{mM}$ and $140 \mathrm{mM}$ for HCT-15 cells and $110 \mathrm{mM}$ and $220 \mathrm{mM}$ for RKO cells) for $48 \mathrm{~h}$ or with fresh complete medium or etoposide $(50 \mu \mathrm{M})$ as a negative and positive control, respectively. Actin was used as a loading control 

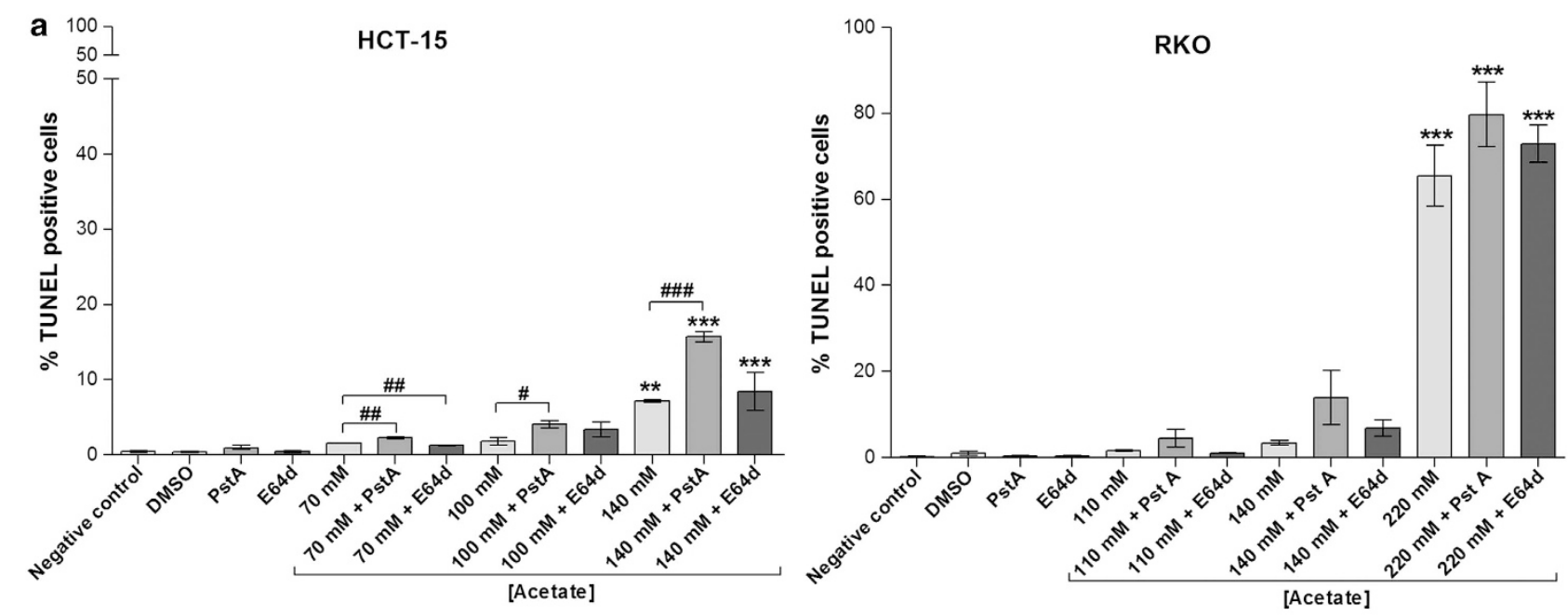

b

HCT-15

[Acetate]
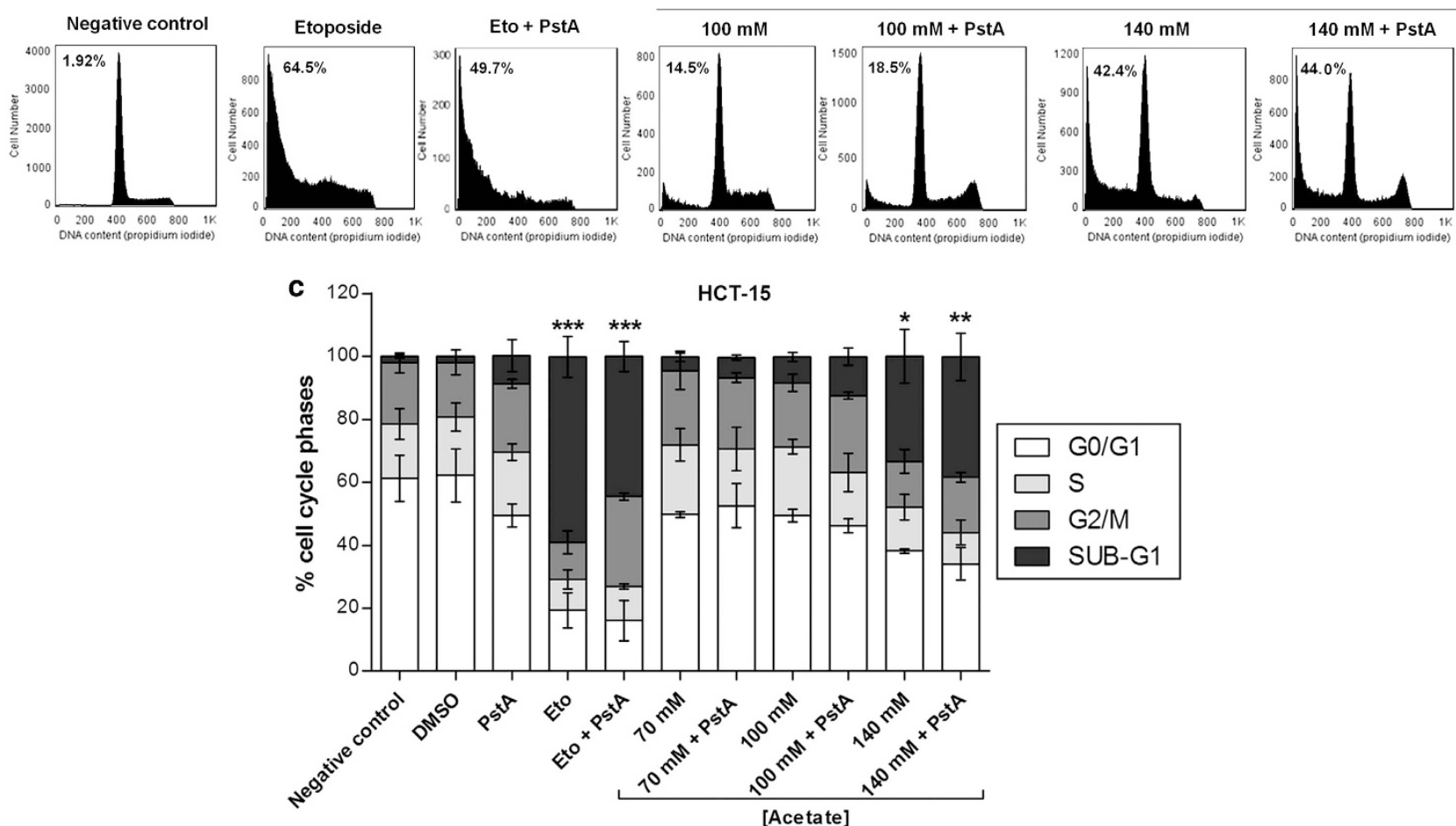

Figure 5 CatD has a protective role in acetate-induced apoptosis. Effect of the specific CatD inhibitor (PstA) and CatB and CatL inhibitor (E64d) on apoptosis in HCT-15 and RKO cells treated with acetate. PstA $(100 \mu \mathrm{M})$ was pre-incubated for $16 \mathrm{~h}$ and then co-incubated with acetate for $48 \mathrm{~h}$. E64d $(10 \mu \mathrm{M})$ was pre-incubated for $1 \mathrm{~h}$ and then co-incubated with acetate for $48 \mathrm{~h}$. (a) Apoptosis analysis by TUNEL assay. Values represent mean \pm S.E.M. of at least three independent experiments. ${ }^{* \star} P \leq 0.01$; ${ }^{* * \star} P \leq 0.001$ compared with negative control cells. \# $P \leq 0.05$; \#\# $P \leq 0.01$; \#\#\# $P \leq 0.001$ comparing acetate treatment with or without PstA or E64d. (b) Analysis of the effect PstA on the sub-G1 subpopulation of acetate-treated HCT-15 cells by flow cytometry. Representative histograms corresponding to HCT-15 cells treated with $100 \mathrm{mM}$ and $140 \mathrm{mM}$ acetate with or without PstA. Percentage of sub-G1 cells are shown. Cells were incubated with fresh complete medium or etoposide $(50 \mu \mathrm{M})$ as a negative and positive control, respectively. (c) Analysis of the distribution of cell-cycle phases in HCT-15 cells after acetate treatment in absence/presence of PstA. Values represent mean \pm S.E.M. of at least three independent experiments. ${ }^{\star} P \leq 0.05 ;{ }^{* *} P \leq 0.01 ;{ }^{* \star *} P \leq 0.001$ comparing the percentage of sub-G1 populations of treated cells with that of untreated cells (negative control/dimethyl sulfoxide (DMSO))

\section{Discussion}

$\mathrm{CRC}$ is a leading cause of mortality in Europe, and its global therapeutics market is worth billions of Euros (GLOBOCAN). Worldwide variations in colorectal cancer incidence suggest that dietary and lifestyle factors contribute to its etiology and are important risk factors for CRC. CRC is most susceptible to dietary influence, and a higher intake of dietary fibers can reduce the risk of CRC. ${ }^{22}$ SCFA, particularly propionate and acetate, are the end products of fermentation of physiological bacteria, namely propionibacteria, which are present in dietary fibers and several dairy products frequently consumed. ${ }^{23}$ Both 
Table 1 Measurement of $\mathrm{pH}$ in acetate-treated cells

\begin{tabular}{ll}
\hline Condition & $\mathbf{p H}$ \\
\hline$H C T-15$ & \\
RPMI & 7.45 \\
Untreated cells & 7.07 \\
Acetate & \\
$70 \mathrm{mM}$ & 7.18 \\
$100 \mathrm{mM}$ & 6.93 \\
$140 \mathrm{mM}$ & 7.06 \\
$R K O$ & \\
DMEM & 8.00 \\
Untreated cells & 8.01 \\
Acetate & \\
$110 \mathrm{mM}$ & 8.01 \\
$140 \mathrm{mM}$ & 8.20 \\
$220 \mathrm{mM}$ & 8.16 \\
\end{tabular}

Determination of $\mathrm{pH}$ values in the culture medium of $\mathrm{CRC}$ cells, after incubation with acetate for $48 \mathrm{~h}$. Untreated cells were incubated with fresh complete medium. Data represent means of at least three independent experiments

pure SCFA and propionibacteria culture supernatants from the dairy species Propionibacterium freudenreichii and Propionibacterium acidipropionici induce apoptosis in CRC cells in vitro. ${ }^{1-3}$ Moreover, administration of $P$. freudenreichii in vivo significantly increased the number of apoptotic epithelial cells damaged by 1,2-dimethylhydrazine, a carcinogenic agent, without affecting the survival of healthy normal colonic mucosa. ${ }^{4,5}$ These characteristics indicate that propionibacteria might have a protective role against colon cancer, acting as a probiotic, and point to a useful role of propionibacteria and their metabolites propionate, butyrate and acetate as powerful agents for CRC prevention or therapy.

We showed that acetate per se induces apoptosis in CRC-derived cell lines HCT-15 and RKO, by inducing DNA fragmentation, caspase activation, phosphatidylserine exposure to the outer leaflet of the plasma membrane and the appearance of a sub-G1 population. The concentrations used in our study were in the physiological range; total SCFA concentrations from $50-200 \mathrm{mM}$ have been reported in the intestinal lumen of a wide range of vertebrates and in most cases remain at constant high levels throughout the bowel length. ${ }^{24,25}$ Our results are thus in agreement with previous reports showing that propionibacteria supernatants, as well as pure acetate and/or propionate, induce apoptosis in HT-29 and CACO-2 CRC cell lines. ${ }^{3}$ In these cells, a mixture of acetate and propionate induced caspase 3 activation, nuclei shrinkage, chromatin condensation and nuclei fragmentation into apoptotic bodies. It was also demonstrated that mitochondria have a critical role in this process, evidenced by increased mitochondrial outer membrane permeability and enhanced reactive oxygen species accumulation in response to acetate and propionate, alone or in combination. ${ }^{3}$ These authors also identified the mitochondrial adenine nucleotide translocator (ANT) as a potential SCFA target, suggesting that mitochondria and ANT are involved in the cell death pathway. ${ }^{3}$

The cell microenvironment may be a determinant for the type of cell death induced by toxic stimuli. The $\mathrm{pH}$ of the human colon lumen ranges from 5.5-7.5. SCFA produced by $P$. freudenreichii trigger apoptosis in HT-29 cells at $\mathrm{pH} 7.5$ but necrosis at $\mathrm{pH}$ 5.5. At $\mathrm{pH} 7.5$, propionibacterial SCFA were shown to induce cell-cycle arrest in the G2/M phase and morphological characteristics of apoptotic cell death, like membrane blebbing, chromatin condensation and fragmentation, phosphatidylserine exposure and formation of apoptotic bodies. ${ }^{1}$ In accordance with these reports, we showed that acetate induces apoptosis in HCT-15 and RKO cells without altering the extracellular $\mathrm{pH}$ (complete medium). We also demonstrated that acetate alone inhibits proliferation in both the cell lines, in agreement with previous reports. ${ }^{1}$

We have previously demonstrated in the yeast $S$. cerevisiae that acetic acid induces a mitochondria-mediated apoptotic process ${ }^{18}$ with several features similar to apoptosis induced by SCFA in CRC cells. Notably, the mitochondrial inner membrane AAC carrier, the yeast ortholog of mammalian ANT, was required for mitochondrial outer membrane permeabilization and cytochrome $c$ release in yeast cells committed to apoptosis induced by acetic acid. We also observed that Pep4p, the yeast CatD, was released from the lysosome-like vacuole to the cytosol in response to acetic acid. ${ }^{18}$ As acetic acid and acetate trigger apoptosis through an analogous pathway in both yeast and CRC cells, respectively, we hypothesized that partial LMP with CatD release might also be involved in acetate-induced apoptosis in CRC cells. The involvement of lysosomes in apoptotic cell death, mainly through partial LMP, has gained increased attention. ${ }^{7}$ It is now established that they are important contributors to cancer cell death, increasing interest in exploiting lysosomal cell death pathways as a potential target in cancer therapy. ${ }^{10}$ LMP followed by release of lysosomal contents to the cytosol, especially cathepsins, seems to be the critical step of the lysosomal death pathway. The most relevant human cathepsins are the proteases CatB and CatL and the sole lysosomal aspartic protease CatD. They are most abundant in the lysosome ${ }^{26}$ and remain active at a neutral $\mathrm{pH}^{27}$ Overexpression of cathepsins often occurs in human cancers, and high levels of their expression can be associated with increased risk of relapse and poor prognosis. ${ }^{13}$ However, besides the tumor-promoting effects of these proteases, there is evidence that cathepsins may also function as tumor suppressors. ${ }^{14}$

Little is known about the role of the lysosomal pathway in cell death regulation in $\mathrm{CRC}$. It has been shown that resveratrol, a naturally occurring polyphenol, triggers a caspase-dependent intrinsic pathway of apoptosis involving lysosomal CatD in CRC cells. The authors provide evidence that CatD, though not CatB or CatL, mediates resveratrol cytotoxicity in DLD1 and HT29 cell lines, inducing lysosome leakage with increased cytosolic CatD. ${ }^{28}$ In this study, we aimed to investigate the mechanisms underlying acetateinduced apoptosis in CRC cells, focusing on the role of the lysosomal pathway through LMP and CatD release. We showed, for the first time, by different approaches that exposure of CRC cells to acetate leads to LMP, release of CatD to the cytosol and accumulation of Pro-CatD and mature CatD. We also showed that inhibiting CatD with PstA, a widely used specific inhibitor of CatD enzymatic activity, ${ }^{21,28-33}$ increased acetate-induced apoptosis in CRC cells. Interestingly, in yeast, deletion of Pep4p confers higher susceptibility to acetic acid, while cells overexpressing Pep4p display higher resistance. ${ }^{18}$ Recently, it has also been demonstrated that Pep4p has a dual cytoprotective function, anti-apoptotic 
and anti-necrotic, during $S$. cerevisiae chronological aging via the polyamine pathway. ${ }^{34}$ Our data in CRC cells are thus in agreement with the results obtained in yeast. Taken together, our results point to a function of CatD in cell protection rather than in the execution of acetate-induced cell death, in both $\mathrm{CRC}$ and yeast.

The role of CatD expression in colon carcinogenesis is controversial and poorly understood. CatD protein levels in CRC clinical cases show divergent expression patterns, suggesting a complex regulation and function of this protease. ${ }^{17,28,35-41}$ One study showed that the average CatD protein content was not different in $59 \mathrm{CRC}$ when compared with normal mucosa, but individual tumors demonstrated marked changes in CatD expression levels. ${ }^{16}$ Measurement of protein content of tumor versus normal pairs on western blots revealed loss of CatD in $>50 \%$ of CRC. However, two-fold increases in CatD protein levels were also observed in $\sim 1 / 3$ of tumors, supporting the concept that CRC develop via divergent molecular pathways and that CatD may function differently in different cancers. ${ }^{16}$ Another study analyzed surgical specimens of 100 primary CRC with different grades of differentiation and determined that immunoreactivity for CatD was negative in the cytoplasm of normal colorectal epithelial cells adjacent to carcinoma. CatD expression in carcinoma cells was present in $68 \%$ of the cases, and CatD positivity was higher when the grade of differentiation was higher. ${ }^{17}$ Yet another study showed that the majority of CRC (93/106) stained positive for CatD, whereas normal colon was almost completely negative. ${ }^{35}$ It is therefore apparent that some, but not all, CRC cells overexpress CatD in comparison to normal colon mucosa.

In the present study, we showed that CRC cell lines HCT-15 and RKO express CatD and are sensitive to physiological levels of acetate, suggesting that the levels of CatD observed might differ from those of normal colon cells. However, we could not test this hypothesis 'in vitro' because the only available 'normal' human colon mucosal epithelium-derived cells NCM460 (INCELL Corporation, San Antonio, TX, USA $)^{42}$ also express CatD and behave similarly to RKO cells in response to acetate (data not shown). According to information provided by INCELL, NCM460 cells have acquired a tumorigenic phenotype due to their extended time in culture.

The protective role of CatD demonstrated by our data might partly explain why CatD is overexpressed in some CRC clinical cases in comparison to normal colon mucosa. We therefore hypothesize that increased expression of this protease might be beneficial to cancer cells and thus that CatD might have an 'oncogenic-like effect', allowing CRC cells to survive in the presence of physiological levels of SCFA in the colon.

In summary, our novel findings show that acetate induces partial LMP and consequent release of CatD to the cytosol in $\mathrm{CRC}$ cells. Our results also indicate that inhibition of CatD enzymatic activity sensitizes CRC cells to acetate-induced apoptosis, suggesting that CatD, like Pep4p in yeast, might have a protective role in this process. However, the mechanism involved remains elusive and will warrant further investigation. Our observations indicate that CatD protects cells from acetate exposure, prompting further exploiting the differential sensitivity of $\mathrm{CRC}$ to acetate. Inhibiting CatD function therefore emerges as a novel prevention/ therapeutic strategy in CRCs, particularly in the case of CRCs with decreased levels of CatD. Specifically increasing the sensitivity of CatD-overexpressing CRCs without affecting normal colon mucosa cells will likely require nanodelivery systems of CatD inhibitors such as PstA to specifically target CRC cells, in combination with strategies to increase acetate concentrations in the colon, namely emerging nutraceuticals.

\section{Materials and Methods}

Cell lines and culture conditions. HCT-15 and RKO cell lines derived from human $\mathrm{CRC}$ were maintained at $37^{\circ} \mathrm{C}$ under a humidified atmosphere containing $5 \% \mathrm{CO}_{2}$. HCT-15 cells were grown in RPMI medium with L-glutamine and HEPES supplemented with $10 \%$ heat inactivated fetal bovine serum, $100 \mathrm{U} / \mathrm{ml}$ penicillin/streptomycin. RKO cells were grown in DMEM supplemented with $1 \mathrm{mM}$ sodium pyruvate, $1.5 \mathrm{~g} / \mathrm{l}$ sodium bicarbonate, $10 \%$ fetal bovine serum, $100 \mathrm{U} / \mathrm{ml}$ penicillin/streptomycin. Cells were seeded and adhered onto appropriate sterile plates for $24 \mathrm{~h}$ before treatments.

Assessment of cell viability by MTT reduction assay. Cells were incubated with different concentrations of sodium acetate, henceforth referred to as acetate, for $48 \mathrm{~h}$. Freshly prepared MTT was added at a final concentration of $0.5 \mathrm{mg} / \mathrm{ml}$ in PBS pH 7.4 and plates incubated in the dark for $2 \mathrm{~h}$ at $37^{\circ} \mathrm{C}$. In all, $500 \mu \mathrm{l}$ of acidic isopropanol $(0.04 \mathrm{M} \mathrm{HCl}$ in absolute isopropanol) were added to each well, followed by $30 \mathrm{~min}$ of orbital shaking in the dark, to solubilize the formazan crystals. Absorbance was read at $570 \mathrm{~nm}$ in a microplate reader (SpectraMax 340PC, Molecular Devices, Sunnyvale, CA, USA). Results were expressed as a percentage of sample absorbance in relation to the negative control (untreated cells).

\section{Cell proliferation assays}

SRB: Cells were incubated with different acetate concentrations for $48 \mathrm{~h}$, fixed in ice-cold methanol containing $1 \%$ acetic acid, and incubated with $0.5 \%$ (w/v) SRB dissolved in $1 \%$ acetic acid for $1.5 \mathrm{~h}$ at $37^{\circ} \mathrm{C}$. After washing with $1 \%$ acetic acid, SRB was solubilized with $10 \mathrm{mM}$ Tris, $\mathrm{pH} 10$. Absorbance was read at $540 \mathrm{~nm}$ in a microplate reader (SpectraMax 340PC Molecular Devices). Results were expressed relatively to the negative control (untreated cells), which was considered as $100 \%$ of cell proliferation.

BrdU incorporation: Cells were seeded in plates containing glass coverslips, exposed to acetate for $48 \mathrm{~h}$ and incubated with $10 \mu \mathrm{M}$ BrdU for $1 \mathrm{~h}$. Cells were fixed with $4 \%$ paraformaldehyde and nuclear incorporation of BrdU was detected by immunofluorescence. Coverslips were mounted on Vectashield Mounting Medium with DAPI (4',6-diamidino-2-phenylindole) and the percentage of positive nuclei (BrdU index) was determined from $>500$ cells/datum point.

\section{Apoptosis assays}

TUNEL: Cells were exposed to DMSO control, etoposide or different concentrations of acetate for $48 \mathrm{~h}$. When cathepsin inhibitors were used, cells were preincubated with PstA or E64d for $16 \mathrm{~h}$ and $1 \mathrm{~h}$, respectively, and then co-incubated with acetate or etoposide for $48 \mathrm{~h}$. Cytospins of both floating and attached cells were fixed with $4 \%$ paraformaldehyde for $15 \mathrm{~min}$ at room temperature (RT). Cells were washed in PBS and permeabilized with ice-cold $0.1 \%$ Triton X-100 in $0.1 \%$ sodium citrate. TUNEL was performed following the manufacturer's instructions ('In situ cell death detection kit, fluorescein', Roche, Mannheim, Germany). Slides were mounted on Vectashield Mounting Medium with DAPI and maintained at $-20^{\circ} \mathrm{C}$ until visualization in a fluorescence microscope (Leica DM 5000B, Leica Microsystems, Wetzlar, Germany).

Caspase 3 activity. Cells were exposed to etoposide or acetate for $48 \mathrm{~h}$. Both floating cells and attached cells were collected, washed twice with PBS, and lysed in Lysis Buffer (10 mM Tris, pH 7.5, 0.1 M NaCl, 1 mM EDTA, 0.01\% Triton X-100) through three freeze/thaw cycles. In all, $50 \mu$ lof total extracts $(1 \mathrm{mg} / \mathrm{ml})$ were incubated with $50 \mu \mathrm{l} 200 \mu \mathrm{M}$ z-DEVD-AFC (Biomol, Plymouth Meeting, PA, USA) 
in $2 \times$ reaction buffer (20 mM PIPES, pH 7.4, $4 \mathrm{mM}$ EDTA, $10 \mathrm{mM}$ DTT) and fluorescence of cleaved AFC was measured using a fluorescence microplate reader (Fluoroskan Ascent FL, Thermo Fisher Scientific Inc., Waltham, MA, USA).

AV/PI staining: Cells were treated with etoposide or acetate for $48 \mathrm{~h}$. Both floating and attached cells were collected and washed in PBS. In all, $1 \times 10^{6}$ cells were resuspended in $200 \mu \mathrm{l} 1 \times$ binding buffer and incubated with $8 \mu \mathrm{l}$ AV-fluorescein isothiocyanate (BD Biosciences, San Jose, CA, USA) and $15 \mu \mathrm{l} 50 \mu \mathrm{g} / \mathrm{ml} \mathrm{PI}$ for $15 \mathrm{~min}$ in the dark. Samples were analyzed in a flow cytometer (Epics XL, Beckman Coulter, Miami, FL, USA) equipped with an argon-ion laser emitting a 488-nm beam at $15 \mathrm{~mW}$. Monoparametric detection of red fluorescence was performed using FL-3 $(488 / 620 \mathrm{~nm})$ and detection of green fluorescence was performed using FL-1 (488/ $525 \mathrm{~nm}$ ). In all, 20000 cells were analyzed per sample and data analyzed using FlowJo software (version 7.6, Tree Star Inc., Ashland, OR, USA).

Sub-G1 cell population analysis: Cells were treated with DMSO, etoposide or acetate for $48 \mathrm{~h}$. When PstA was used, cells were pre-incubated as described above. Both floating and attached cells were collected, washed with PBS and incubated with $70 \%$ cold ethanol for $15 \mathrm{~min}$. Cells were then washed twice with PBS, incubated with RNase A $(200 \mu \mathrm{g} / \mathrm{ml})$ for $15 \mathrm{~min}$ in the dark at $37^{\circ} \mathrm{C}$ and with propidium iodide $(0.5 \mathrm{mg} / \mathrm{ml})$ for $30 \mathrm{~min}$ at RT before analysis on a flow cytometer, as described above. FlowJo software was used to generate DNA content frequency histograms and quantify the amount of cells in the individual cell-cycle phases, including the sub-G1 population assumed as corresponding to apoptotic cells.

\section{LMP assessment}

AO staining analysis by fluorescence microscopy: Cells were seeded in six-well plates containing glass coverslips, and exposed to etoposide or acetate for $48 \mathrm{~h}$. Cells were then incubated with $1 \mu \mathrm{M} \mathrm{AO}$ for $15 \mathrm{~min}$ at $37^{\circ} \mathrm{C}$ and washed with PBS. Coverslips were mounted over glass slides with PBS and immediately observed and photographed using a fluorescence microscope (Leica DM 5000B).

AO staining analysis by flow cytometry: Cells were exposed to etoposide or acetate for $48 \mathrm{~h}$. Both floating and attached cells were collected, washed with PBS and resuspended in PBS to a final concentration of $1 \times 10^{6}$ cells in $1.5 \mathrm{ml}$. Cells were then incubated with $1 \mu \mathrm{M} \mathrm{AO}$ (or without $\mathrm{AO}$ to measure autofluorescence) for $15 \mathrm{~min}$ at $37^{\circ} \mathrm{C}$.

\section{Immunoblot detection of cathepsin D}

Preparation of cytosolic protein extracts: Cells were exposed to etoposide or acetate for $48 \mathrm{~h}$. Both floating and attached cells were collected, washed with PBS and centrifuged at $650 \times g$ for $10 \mathrm{~min}$ at $4^{\circ} \mathrm{C}$. All subsequent steps were performed at $4{ }^{\circ} \mathrm{C}$. Cells were resuspended in $1 \mathrm{ml}$ PBS, centrifuged at $1500 \times \mathrm{g}$ for $5 \mathrm{~min}$ and washed twice in $800 \mu$ l Isotonic Buffer $(200 \mathrm{mM}$ mannitol, $70 \mathrm{mM}$ sucrose, $1 \mathrm{mM}$ EGTA, $10 \mathrm{mM}$ HEPES) by centrifugation at $3000 \times g$ for $5 \mathrm{~min}$. The cell pellet was then resuspended in $300 \mu$ l Isotonic Buffer with $20 \mathrm{mM} \mathrm{NaF}, 20 \mathrm{mM}$ $\mathrm{Na}_{3} \mathrm{VO}_{4}, 1 \mathrm{mM}$ PMSF and $40 \mu \mathrm{l} / \mathrm{ml}$ Protease inhibitor cocktail and homogenized by passing through a $26-\mathrm{G}$ needle 70 times. Nuclei and unbroken cells were removed by centrifugation at $1000 \times g$ for $5 \mathrm{~min}$, followed by two consecutive centrifugations, first at $10000 \times g$ for $15 \mathrm{~min}$ to remove lysosomes and mitochondria and then at $100000 \times g$ for $1 \mathrm{~h}$ in an ultracentrifuge. Cytosolic protein extracts were stored at $-80^{\circ} \mathrm{C}$.

Preparation of total protein extracts: Cells were exposed to etoposide or acetate for $48 \mathrm{~h}$. Both floating and attached cells were collected, washed with PBS and centrifuged at $650 \times g$ for $5 \mathrm{~min}$ at $4{ }^{\circ} \mathrm{C}$. The supernatant was discarded and cells lysed in $80 \mu$ l Ripa Buffer (50 mM Tris-HCl pH 7.5, $150 \mathrm{mM} \mathrm{NaCl}, 2 \mathrm{mM}$ EDTA, $1 \%$ NP-40) supplemented with $20 \mathrm{mM} \mathrm{NaF}, 20 \mathrm{mM} \mathrm{Na}_{3} \mathrm{VO}_{4}, 1 \mathrm{mM} \mathrm{PMSF}$ and $40 \mu \mathrm{l} / \mathrm{ml}$ Protease inhibitor cocktail. Supernatants were cleared by centrifugation at $4500 \times \mathrm{g}$ for $10 \mathrm{~min}$. Total protein extracts were stored at $-80^{\circ} \mathrm{C}$.

Western blot analysis: Protein samples $(25 \mu \mathrm{g})$ were separated by sodium dodecyl sulfate $12,5 \%$ polyacrylamide gel electrophoresis and electroblotted onto PVDF (polyvinylidene difluoride) membranes. Primary antibodies were anticathepsin D (Calbiochem, San Diego, CA, USA) and anti-actin (Santa Cruz Biotechnology, Santa Cruz, CA, USA). Secondary antibodies were peroxidaseconjugated AffiniPure goat anti-rabbit IgG (Jackson ImmunoResearch, West
Grove, PA, USA) and horseradish peroxidase-labeled goat anti-mouse immunoglobulin IgG (Jackson ImmunoResearch). Subsequent chemiluminescence detection was performed using the ECL detection system (Amersham, Biosciences, Buckinghamshire, UK) and a molecular imager (Chemi-Doc XRS system, Bio-Rad, Laboratories Inc., Hercules, CA, USA).

Statistical analysis: Data are expressed as means \pm S.E.M. of at least three independent experiments. Statistical analysis between negative control and treated samples was performed by one-way ANOVA followed by Dunnett's test and the comparison between PstA- or E64d-treated and untreated cells was performed by unpaired two-tailed Student's $t$-test. Differences were considered significant when $P \leq 0.05$.

\section{Conflict of Interest}

The authors declare no conflict of interest.

Acknowledgements. This work was supported by the Fundação para a Ciência e Tecnologia (FCT) research project PTDC/BIA-BCM/69448/2006 and FCT PhD grants for SA (SFRH/BD/64695/2009) and CO (SFRH/BD/77449/2011). This work was also supported by FEDER through POFC-COMPETE, and by national funds from FCT through the project PEst-C/BIA/UI4050/2011.

1. Lan A, Lagadic-Gossmann D, Lemaire C, Brenner C, Jan G. Acidic extracellular pH shifts colorectal cancer cell death from apoptosis to necrosis upon exposure to propionate and acetate, major end-products of the human probiotic propionibacteria. Apoptosis 2007; 12: 573-591.

2. Ruemmele FM, Schwartz S, Seidman EG, Dionne S, Levy E, Lentze MJ. Butyrate induced Caco-2 cell apoptosis is mediated via the mitochondrial pathway. Gut 2003; 52: 94-100.

3. Jan G, Belzacq AS, Haouzi D, Rouault A, Metivier D, Kroemer G et al. Propionibacteria induce apoptosis of colorectal carcinoma cells via short-chain fatty acids acting on mitochondria. Cell Death Differ 2002; 9: 179-188.

4. Lan A, Bruneau A, Bensaada M, Philippe C, Bellaud P, Rabot S et al. Increased induction of apoptosis by Propionibacterium freudenreichii TL133 in colonic mucosal crypts of human microbiota-associated rats treated with 1,2-dimethylhydrazine. Br J Nutr 2008; 100: 1251-1259.

5. Lan A, Bruneau A, Philippe C, Rochet V, Rouault A, Herve C et al. Survival and metabolic activity of selected strains of Propionibacterium freudenreichii in the gastrointestinal tract of human microbiota-associated rats. Br J Nutr 2007; 97: 714-724.

6. Hinnebusch BF, Meng S, Wu JT, Archer SY, Hodin RA. The effects of short-chain fatty acids on human colon cancer cell phenotype are associated with histone hyperacetylation. J Nutr 2002; 132: 1012-1017.

7. Guicciardi ME, Leist M, Gores GJ. Lysosomes in cell death. Oncogene 2004; 23: 2881-2890.

8. Kågedal $\mathrm{K}$, Johansson $\mathrm{AC}$, Johansson $\mathrm{U}$, Heimlich $\mathrm{G}$, Roberg $\mathrm{K}$, Wang NS et al. Lysosomal membrane permeabilization during apoptosis-involvement of Bax? Int J Exp Pathol 2005; 86: 309-321.

9. Tardy C, Codogno P, Autefage H, Levade T, Andrieu-Abadie N. Lysosomes and lysosomal proteins in cancer cell death (new players of an old struggle). Biochim Biophys Acta Rev Cancer 2006; 1765: 101-125.

10. Kirkegaard T, Jäättelä M. Lysosomal involvement in cell death and cancer. Biochim Biophys Acta Mol Cell Res 2009; 1793: 746-754.

11. Mohamed MM, Sloane BF. Cysteine cathepsins: multifunctional enzymes in cancer. Nat Rev Cancer 2006; 6: 764-775.

12. Joyce JA, Baruch A, Chehade K, Meyer-Morse N, Giraudo E, Tsai F-Y et al. Cathepsin cysteine proteases are effectors of invasive growth and angiogenesis during multistage tumorigenesis. Cancer Cell 2004; 5: 443-453.

13. Palermo C, Joyce JA. Cysteine cathepsin proteases as pharmacological targets in cancer. Trends Pharmacol Sci 2008; 29: 22-28.

14. Lopez-Otin C, Matrisian LM. Emerging roles of proteases in tumour suppression. Nat Rev Cancer 2007; 7: 800-808.

15. Nicotra G, Castino R, Follo C, Peracchio C, Valente G, Isidoro C. The dilemma: does tissue expression of cathepsin $D$ reflect tumor malignancy? The question: does the assay truly mirror cathepsin D mis-function in the tumor? Cancer Biomark 2010; 7: 47-64.

16. lacobuzio-Donahue C, Shuja S, Cai J, Peng P, Willett J, Murnane MJ. Cathepsin D protein levels in colorectal tumors: divergent expression patterns suggest complex regulation and function. Int J Oncol 2004; 24: 473-485.

17. Yilmaz F, Uzunlar AK, Kilinc N, Yilmaz HG. Expression of cathepsin D in colorectal adenocarcinomas: correlation with clinicopathologic features. Ann Saudi Med 2003; 23: 208-211.

18. Pereira C, Chaves S, Alves S, Salin B, Camougrand N, Manon S et al. Mitochondrial degradation in acetic acid-induced yeast apoptosis: the role of Pep4 and the ADP/ATP carrier. Mol Microbiol 2010; 76: 1398-1410. 
19. Groth-Pedersen L, Ostenfeld MS, Hoyer-Hansen M, Nylandsted J, Jaattela M. Vincristine induces dramatic lysosomal changes and sensitizes cancer cells to lysosome-destabilizing siramesine. Cancer Res 2007; 67: 2217-2225.

20. Fehrenbacher N, Bastholm L, Kirkegaard-Sørensen T, Rafn B, Bøttzauw T, Nielsen C et al. Sensitization to the lysosomal cell death pathway by oncogene-induced down-regulation of lysosome-associated membrane proteins 1 and 2. Cancer Res 2008; 68: 6623-6633.

21. Emert-Sedlak L, Shangary S, Rabinovitz A, Miranda MB, Delach SM, Johnson DE. Involvement of cathepsin D in chemotherapy-induced cytochrome $c$ release, caspase activation, and cell death. Mol Cancer Ther 2005; 4: 733-742.

22. Bingham SA, Day NE, Luben R, Ferrari $P$, Slimani N, Norat T et al. Dietary fibre in food and protection against colorectal cancer in the European Prospective Investigation into Cance and Nutrition (EPIC): an observational study. Lancet 2003; 361: 1496-1501.

23. Britz T, Steyn P. Volatile fatty acid production by the dairy and clinical propionibacteria and related coryneforms. Phytophylactica 1979; 11: 111-115.

24. Titus $\mathrm{E}$, Ahearn GA. Short-chain fatty acid transport in the intestine of a herbivorous teleost. J Exp Biol 1988; 135: 77-94.

25. Scharrer E, Amstutz I, Grenacher B. Inhibition of mucosal glycylsarcosine uptake by acetate in rat distal small intestine. Exp Physiol 1999; 84: 541-548.

26. Turk B, Stoka V, Rozman-Pungercar J, Cirman T, Droga-Mazovec G, Oresic $\mathrm{K}$ et al. Apoptotic pathways: involvement of lysosomal proteases. Biol Chem 2002; 383: 1035-1044.

27. Boya P, Kroemer G. Lysosomal membrane permeabilization in cell death. Oncogene 2008; 27: $6434-6451$

28. Trincheri NF, Nicotra G, Follo C, Castino R, Isidoro C. Resveratrol induces cell death in colorectal cancer cells by a novel pathway involving lysosomal cathepsin D. Carcinogenesis 2007; 28: 922-931.

29. Kagedal $K$, Johansson $U$, Ollinger $K$. The lysosomal protease cathepsin $D$ mediates apoptosis induced by oxidative stress. FASEB J 2001; 15: 1592-1594.

30. Johansson AC, Steen $\mathrm{H}$, Ollinger K, Roberg K Cathepsin D mediates cytochrome release and caspase activation in human fibroblast apoptosis induced by staurosporine. Cell Death Differ 2003; 10: 1253-1259.

31. Deiss LP, Galinka H, Berissi H, Cohen O, Kimchi A. Cathepsin D protease mediates programmed cell death induced by interferon-gamma, Fas/APO-1 and TNF-alpha. EMBO J 1996; 15: 3861-3870.

32. Chen QY, Shi JG, Yao QH, Jiao DM, Wang YY, Hu HZ et al. Lysosomal membrane permeabilization is involved in curcumin-induced apoptosis of A549 lung carcinoma cells Mol Cell Biochem 2012; 359: 389-398.
33. Li LJ, Zhong LF, Jiang LP, Geng CY, Zhu TZ, Xu YH et al. Lysosomal membrane permeabilization contributes to elemene emulsion-induced apoptosis in A549 cells. Free Radic Res 2011; 45: 1232-1240.

34. Carmona-Gutierrez D, Bauer MA, Ring J, Knauer H, Eisenberg T, Buttner $\mathrm{S}$ et al. The propeptide of yeast cathepsin D inhibits programmed necrosis. Cell Death Dis 2011; 2 : e161.

35. Mayer A, Fritz E, Fortelny R, Kofler K, Ludwig H. Immunohistochemical evaluation of cathepsin D expression in colorectal cancer. Cancer Invest 1997; 15: 106-110.

36. Beaujouin M, Liaudet-Coopman E. Cathepsin D overexpressed by cancer cells can enhance apoptosis-dependent chemo-sensitivity independently of its catalytic activity. Adv Exp Med Biol 2008; 617: 453-461.

37. Kunimura T, Inagaki T, Wada M, Ushio J, Sato K, Enosawa T et al. Immunohistochemical evaluation of tissue-specific proteolytic enzymes in adenomas containing foci of early carcinoma: correlations with cathepsin $\mathrm{D}$ expression and other malignant features. Int $\mathrm{J}$ Gastrointest Cancer 2003; 33: 149-154.

38. Kanber Y, Demirbag NR, Sam AD, Aydin N. Cathepsin D expression in colorectal adenocarcinomas and adenomas. Int J Biol Markers 2002; 17: 165-168.

39. Szajda SD, Snarska J, Jankowska A, Roszkowska-Jakimiec W, Puchalski Z, Zwierz K. Cathepsin $D$ and carcino-embryonic antigen in serum, urine and tissues of colon adenocarcinoma patients. Hepatogastroenterology 2008; 55: 388-393.

40. Arao J, Fukui H, Ono Y, Ueda Y, Chiba T, Fujimori T. Immunohistochemical localization of cathepsin D in colorectal tumors. Dis Colon Rectum 2000; 43: 396-401.

41. Theodoropoulos GE, Panoussopoulos D, Lazaris AC, Golematis BC. Evaluation of cathepsin D immunostaining in colorectal adenocarcinoma. J Surg Oncol 1997; 65: 242-248.

42. Moyer MP, Manzano LA, Merriman RL, Stauffer JS, Tanzer LR. NCM460, a normal human colon mucosal epithelial cell line. In Vitro Cell Dev Biol Anim 1996; 32 : 315-317.

Cell Death and Disease is an open-access journal published by Nature Publishing Group. This work is licensed under the Creative Commons Attribution-NonCommercial-No Derivative Works 3.0 Unported License. To view a copy of this license, visit http://creativecommons.org/licenses/by-nc-nd/3.0/ 